The text itself, moreover, is an essential source for historians of early modernity, as it deals with the moral reformation of the Roman Church but also with the conversion of native Americans, Muslims, and Jews. It is also an essential testimony to the recurrent Renaissance narrative of a new crusade apt to unite the European realms under the Church of Rome and against a common enemy. The introduction to the text does not seem to address all these items in much detail. That said, however, we could not expect a single volume to fill the void that current scholarship leaves open, as its scope is first and foremost to make available with an English translation a significant Latin document of the Italian Renaissance. In doing so quite remarkably, this present volume may count as an exceptional accomplishment.

MARCO PIANA

University of Toronto

\title{
Goodblatt, Chanita.
}

Jewish and Christian Voices in English Reformation Biblical Drama: Enacting Family and Monarch.

Routledge Studies in Renaissance Literature and Culture. London: Routledge, 2017. Pp. xi, $256+15$ figs., 3 tables. ISBN 978-1-4724-7978-5 (hardcover) \$140.

In this broad study, Chanita Goodblatt argues that early modern English biblical dramas of the Hebrew Bible answered questions at the heart of the scriptural texts. She claims that the plays offered a unique interpretation of scriptural texts that aligned with the Protestants' interest in the literal meaning of Scripture, differing from the medieval mystery plays which offered a figurative interpretation of the same Scripture.

Goodblatt's Jewish and Christian Voices in English Reformation Biblical Drama begins with an extensive overview. Her introduction includes a section on "Family and Monarchy" where she argues that the best way to understand the interaction of Bible and drama in Reformation England is through an examination of family and monarchy narratives found in the Hebrew Biblenarratives that reflect the Tudors' familial and dynastic quandaries. The extent of the scope of her analysis can be seen in her thorough examination of three plays-The Enterlude of God Queen Hester (1529-30), The Historie of Jacob 
and Esau (1552-53), and The Love of Kind David and Bethsabe (1594)where she claims that interpretations and conceptions that focus on the relationship between the biblical and literary place emphasis on the revelation and implementation of knowledge (divine/human), the legitimacy of the law (divine/familial), and the issue of identity (gender/religion/nation), which were central to the formation of the family and monarchy.

In the section on "Reading the Bible: Jewish and Christian Voices," Goodblatt claims that she is interested in intertextuality. She demonstrates this later on by examining not only the plays themselves but also their connections with networks of texts such as other biblical texts, relevant historical documents, Christian and Jewish commentaries, and other non-biblical contemporary plays. She argues that the intersection of drama and the Bible portrayed in biblical plays was both textually and performatively important for the Reformers in order to translate and interpret the Bible. She engages with the works of Julia Kristeva and Mikhail Bakhtin, who attempt to understand how language is shared between texts of different genres and how readers respond differently to a different interpretation of the same text. Goodblatt focuses on Bakhtin's discussion of the social context of language which is central to his discussion of "dialogism and heteroglossic discourse" (7) and his view on the continuously evolving meaning of words.

While Goodblatt's examination of intertextuality leaves the readers wanting, her demonstration of the connection between the texts she chose and the biblical text makes her study a unique addition to the field of biblical studies as well as to our understanding of the importance of both Jewish and Christian voices in the history of the Reformation. She writes a brief discussion on the Hebrew narrative of the text with a particular focus on the interpretation of interest to many reformers, including Luther and Calvin. For instance, Goodblatt focuses on Rebecca's agency in Genesis 25 to trace the importance of the representation of female agency through various texts such as the play itself, Jewish and Protestant commentaries, and Protestant devotional guides. Her analyses would be of particular value to anyone interested in the cultural context of these less-studied plays.

Goodblatt's study aligns itself well with recent efforts by early modern scholars to highlight the significance of English plays in understanding biblical scripture. Goodblatt, by exploring the exegetical and performative sides of the English Reformation biblical drama, adds a new dimension to the existing 
scholarship on biblical plays, which places her study with works by David Bevington (Tudor Drama and Politics), Greg Walker (Plays of Persuasion, Reading Literature Historically), and Paul Whitfield White (Theatre and Reformation). Her study is beneficial to readers interested in literature, religion, and the cultural context of biblical plays. It is also helpful in demonstrating the link between different genres of text from different religious traditions.

NILAB FEROZAN

McMaster University

\section{Greenblatt, Stephen.}

Marvelous Possessions: The Wonder of the New World. With a New Preface. Chicago: University of Chicago Press, 2017. Pp. xiv, $202+10$ ill. ISBN 978-0226-52504-5 (paperback) US $\$ 22.50$.

Stephen Greenblatt produced three adept and influential books in just over a decade: Renaissance Self-Fashioning (1980), Shakespearean Negotiations (1988), and Marvelous Possessions (1991), whose re-edition of 2017 I am reviewing here. Over the years, I have either made use of Greenblatt's work in my own scholarship or reviewed his work and books on new historicism, or that "school" itself, sometimes by itself or in relation to cultural materialism, a related movement or endeavour that was associated most with Jonathan Dollimore and Alan Sinfield. While my own work differs from Greenblatt's, I admire him. His work and the wider approaches of new historicism and cultural materialism have made Renaissance studies, cultural studies, and literary studies more interesting. As a writer, literary scholar, and historian, I have found the world much the richer for the work of Greenblatt and others on both sides of the Atlantic, and later globally, who have engaged with text and context in a way that takes history into account.

Greenblatt himself has a nimble mind, bringing wonder to his readers as he fashions himself and negotiates with Shakespeare, the Renaissance, and the New World. He is a fine stylist and writer as well as a bold thinker and teacher. His talks are as marvellous as his books. Greenblatt is what a humanist scholar should be and gives the lie to anyone who would discount literature, history, or the humanities as being unimportant in university or society at large. Arts, 